\title{
Effect of enzymatic transesterification on the fluidity of palm stearin-palm kernel olein mixtures
}

\begin{abstract}
In an effort to improve the physical and/or melting characteristics of solid fats, the enzymatic transesterification of palm stearin-palm kernel olein (40:60) in a solvent-free system was investigated. The enzymes used were Celite-bound lipases that include 1,3-specific lipases such as Aspergillus niger, Alcaligenes sp. and nonspecific lipases such as Pseudomonas sp. and Candida rugosa. Commercial immobilized lipase from Rhizomucor miehei (Lipozyme 1M60) was also used. The efficacies of these enzymes for improving the melting behaviour of the oil mixtures were followed by slip melting point (SMP), solid fat content (SFC) and differential scanning calorimetry (DSC) analyses. Results indicated that enzymatic transesterification was able to produce fat mixtures with substantially lower melting points by repositioning the fatty acids of triglycerides in the higher melting range to form lower- or middle-melting components. Pseudomonas lipase-catalyzed mixtures produced the highest degree $(152.2 \%)$ and rate $(50.0 \mathrm{~h}-1)$ of transesterification followed by R. miehei lipase at $151.7 \%$ and $27.1 \mathrm{~h}-1$, respectively. The highest $\%$ FFA liberated was also from the reaction mixture catalysed by Pseudomonas (2.90\%) and R. miehei (2.54\%) lipases. The Pseudomonas-catalyzed mixture also produced the biggest drop in SMP $\left(12.0^{\circ} \mathrm{C}\right)$ and the SFC results showed complete melting at $35^{\circ} \mathrm{C}$. Our findings also suggest that the positional specificity of lipases may not play a significant role in producing a more fluid product.
\end{abstract}

Keyword: Enzymatic transesterification; Palm stearin-palm kernel olein; Fluidity 